\title{
A Research on Influencing Mechanism of Business Process Outsourcing (BPO) Service Quality
}

\author{
Wang Ye Zhu Yaqian \\ School of Management \\ Tianjin Normal University \\ Tianjin , China \\ wangyetjcn@hotmail.com
}

\begin{abstract}
Based on the Chinese background, this paper, from the contractor perspective, carries out the research on influential factors of BPO service quality and then structural equation models are used to analyze the influencing mechanism of BPO service quality.
\end{abstract}

Keywords-Service Outsourcing ; Business Process Outsourcing (BPO) ; Service Quality ; SEM

\section{THEORETICAL MODEL OF INFLUENTIAL FACTORS OF BPO SERVICE QUALITY}

From the contractor perspective, this paper analyzes the influencing mechanism of BPO service quality by structural equation models including quality control standards, process control, employee-training management, treatment of problem correction and platform construction. The initial scale of the influential factors of BPO service quality is refined and summarized by interviewing service outsourcing experts. According to the participant's opinions which are obtained from a small - scale testing, the initial scale is further improved by correcting the each ambiguous or vague language and then deleting several repetitions or some items which can't reflect measure index. Finally 33 observed variables are shown in table 1.

\section{DATA ACQUISITION OF OBSERVED VARIABLE}

Respondents of the questionnaire survey are mainly outsourcing companies. Questionnaires are distributed mainly in the form of e-mail and paper. Totally 257 questionnaires are sent out including 70 paper questionnaires and 187 e-mail questionnaires. Finally 253 questionnaires are returned and 248 valid ones are retrieved.

To control the way to distribute questionnaire, all respondents are top-level and mid-level management staff in outsourcing enterprises. In addition, the contractees also fill out questionnaires. They put forward a lot of suggestions to improve the questionnaire. It's very useful to guarantee data reliability for maximum.

From the statistical characteristics of the sample, the sample structure of this sampling survey is quite reasonable. Scientific distribution of respondents avoid the uniformity of samples, thereby it can make the conclusions of this study more universal significance.

\section{RESEARCH ASSUMPTIONS THEORETICAL MODEL}

This paper constructs the influential factors of BPO service quality model (Figure1). This model includes five structural variables including quality control standards, process control, employee-training management, treatment of problem correction and the platform construction. Unidirectional arrows between variables represent that the prime determinants affect service quality.

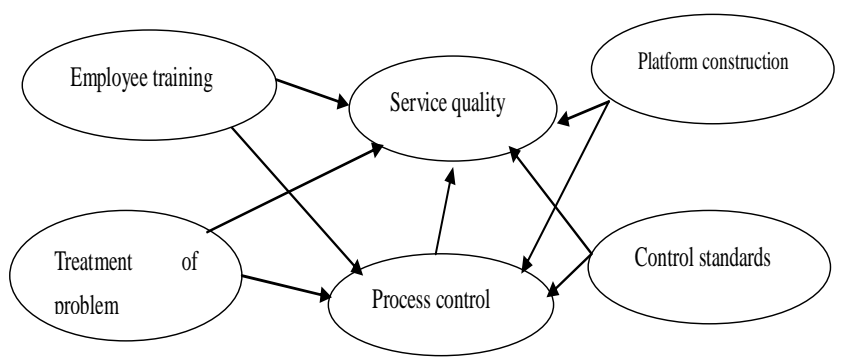

Figure1. The influential factors of BPO service quality Model

According to the previous theoretical model, this paper proposes assumptions of the relationship among all the variables. These assumptions include the relationship among quality control standards, process control, employee-training management, treatment of problem correction and the platform construction, as well as relational structures between service quality and each variable separately. Specific assumptions are as follows:

H1: Quality control standards are positively associated with BPO service quality.

$\mathrm{H} 2$ : Process control is positively associated with BPO service quality.

H3 : Employee-training management is positively associated with BPO service quality.

$\mathrm{H} 4$ : Treatment of problem correction is positively associated with BPO service quality. 
Table1. Variables corresponding table

\begin{tabular}{|c|c|c|c|}
\hline $\begin{array}{c}\text { Latent } \\
\text { variables }\end{array}$ & Observation variables & Latent variables & Observation variables \\
\hline \multirow{4}{*}{ Service quality } & Contractors have good commercial reputation. & \multirow{7}{*}{ Control standards } & $\begin{array}{l}\text { Service contract clearly defines ways of } \\
\text { services supplied. }\end{array}$ \\
\hline & $\begin{array}{l}\text { Contractors have a higher customer } \\
\text { satisfaction. }\end{array}$ & & $\begin{array}{l}\text { Service contract clearly defines the way to } \\
\text { communicate. }\end{array}$ \\
\hline & Contractors have a higher credibility. & & $\begin{array}{l}\text { Service contract clearly defines service time } \\
\text { effectiveness. }\end{array}$ \\
\hline & $\begin{array}{l}\text { Contractors have passed the service quality } \\
\text { standard certification. }\end{array}$ & & $\begin{array}{c}\text { Service contract clearly defines control point of } \\
\text { service standards execution. }\end{array}$ \\
\hline \multirow{9}{*}{$\begin{array}{l}\text { Process } \\
\text { control }\end{array}$} & $\begin{array}{c}\text { Contractors implement management plans } \\
\text { effectively. }\end{array}$ & & $\begin{array}{l}\text { Service contract clearly defines measurement } \\
\text { and evaluation methods of key activities. }\end{array}$ \\
\hline & $\begin{array}{c}\text { Contractors have high-efficiency working } \\
\text { procedure. }\end{array}$ & & \multirow[t]{2}{*}{$\begin{array}{l}\text { Service contract clearly defines the allowable } \\
\text { range of each service characteristic index. }\end{array}$} \\
\hline & $\begin{array}{l}\text { Contractors have highly sophisticated } \\
\text { methods. }\end{array}$ & & \\
\hline & Execute control point during BPO better. & \multirow{4}{*}{$\begin{array}{c}\text { Employee- } \\
\text { training } \\
\text { management }\end{array}$} & Staff is willing to grow. \\
\hline & $\begin{array}{c}\text { Detection and monitoring process of } \mathrm{BPO} \\
\text { quality }\end{array}$ & & Training in post responsibility. \\
\hline & $\begin{array}{c}\text { Staff in working process have good service } \\
\text { attitude. }\end{array}$ & & Training in service attitude. \\
\hline & $\begin{array}{c}\text { Contractors have proper process- control } \\
\text { records. }\end{array}$ & & Services routines and standard training \\
\hline & $\begin{array}{l}\text { Staff in working process communicates } \\
\text { efficiently. }\end{array}$ & & Solve issues in real time in Service process. \\
\hline & The contractees monitor working process & & $\begin{array}{l}\text { The severe dimensions of the problem are } \\
\text { predefined. }\end{array}$ \\
\hline & $\begin{array}{c}\text { Function integrity of computer information } \\
\text { system }\end{array}$ & $\begin{array}{l}\text { Treatment of } \\
\text { problem }\end{array}$ & $\begin{array}{l}\text { Set up issues negotiating mechanism } \\
\text { in advance. }\end{array}$ \\
\hline $\begin{array}{l}\text { Platform } \\
\text { construction }\end{array}$ & $\begin{array}{l}\text { The safety and stability of telecommunication } \\
\text { network }\end{array}$ & & $\begin{array}{l}\text { When problems arise, the corresponding } \\
\text { manager will take responsibility. }\end{array}$ \\
\hline & Stable electric infrastructure & & $\begin{array}{l}\text { Contractors take measures to improve the issue } \\
\text { continuously. }\end{array}$ \\
\hline
\end{tabular}

Table2. Statistical analysis of the basic information of samples

\begin{tabular}{|c|c|c|c|}
\hline $\begin{array}{c}\text { Latent } \\
\text { variables }\end{array}$ & Observation variables & Latent variables & Observation variables \\
\hline \multirow{4}{*}{ Service quality } & Contractors have good commercial reputation. & \multirow{7}{*}{ Control standards } & $\begin{array}{l}\text { Service contract clearly defines ways of } \\
\text { services supplied. }\end{array}$ \\
\hline & $\begin{array}{l}\text { Contractors have a higher customer } \\
\text { satisfaction. }\end{array}$ & & $\begin{array}{l}\text { Service contract clearly defines the way to } \\
\text { communicate. }\end{array}$ \\
\hline & Contractors have a higher credibility. & & $\begin{array}{c}\text { Service contract clearly defines service time } \\
\text { effectiveness. }\end{array}$ \\
\hline & $\begin{array}{l}\text { Contractors have passed the service quality } \\
\text { standard certification. }\end{array}$ & & $\begin{array}{l}\text { Service contract clearly defines control point of } \\
\text { service standards execution. }\end{array}$ \\
\hline \multirow{9}{*}{ Process control } & $\begin{array}{c}\text { Contractors implement management plans } \\
\text { effectively. }\end{array}$ & & $\begin{array}{l}\text { Service contract clearly defines measurement } \\
\text { and evaluation methods of key activities. }\end{array}$ \\
\hline & $\begin{array}{c}\text { Contractors have high-efficiency working } \\
\text { procedure. }\end{array}$ & & \multirow[t]{2}{*}{$\begin{array}{l}\text { Service contract clearly defines the allowable } \\
\text { range of each service characteristic index. }\end{array}$} \\
\hline & $\begin{array}{l}\text { Contractors have highly sophisticated } \\
\text { methods. }\end{array}$ & & \\
\hline & Execute control point during BPO better. & \multirow{4}{*}{$\begin{array}{c}\text { Employee-training } \\
\text { management }\end{array}$} & Staff is willing to grow. \\
\hline & $\begin{array}{c}\text { Detection and monitoring process of } \mathrm{BPO} \\
\text { quality }\end{array}$ & & Training in post responsibility. \\
\hline & $\begin{array}{l}\text { Staff in working process have good service } \\
\text { attitude. }\end{array}$ & & Training in service attitude. \\
\hline & $\begin{array}{c}\text { Contractors have proper process- control } \\
\text { records. }\end{array}$ & & Services routines and standard training \\
\hline & $\begin{array}{c}\text { Staff in working process communicates } \\
\text { efficiently. }\end{array}$ & & Solve issues in real time in Service process. \\
\hline & The contractees monitor working process & & $\begin{array}{c}\text { The severe dimensions of the problem are } \\
\text { predefined. }\end{array}$ \\
\hline & $\begin{array}{l}\text { Function integrity of computer information } \\
\text { system }\end{array}$ & $\begin{array}{l}\text { Treatment of } \\
\text { problem }\end{array}$ & $\begin{array}{l}\text { Set up issues negotiating mechanism } \\
\text { in advance. }\end{array}$ \\
\hline $\begin{array}{l}\text { Platform } \\
\text { construction }\end{array}$ & $\begin{array}{c}\text { The safety and stability of telecommunication } \\
\text { network }\end{array}$ & & $\begin{array}{l}\text { When problems arise, the corresponding } \\
\text { manager will take responsibility. }\end{array}$ \\
\hline & Stable electric infrastructure & & $\begin{array}{l}\text { Contractors take measures to improve the issue } \\
\text { continuously. }\end{array}$ \\
\hline
\end{tabular}




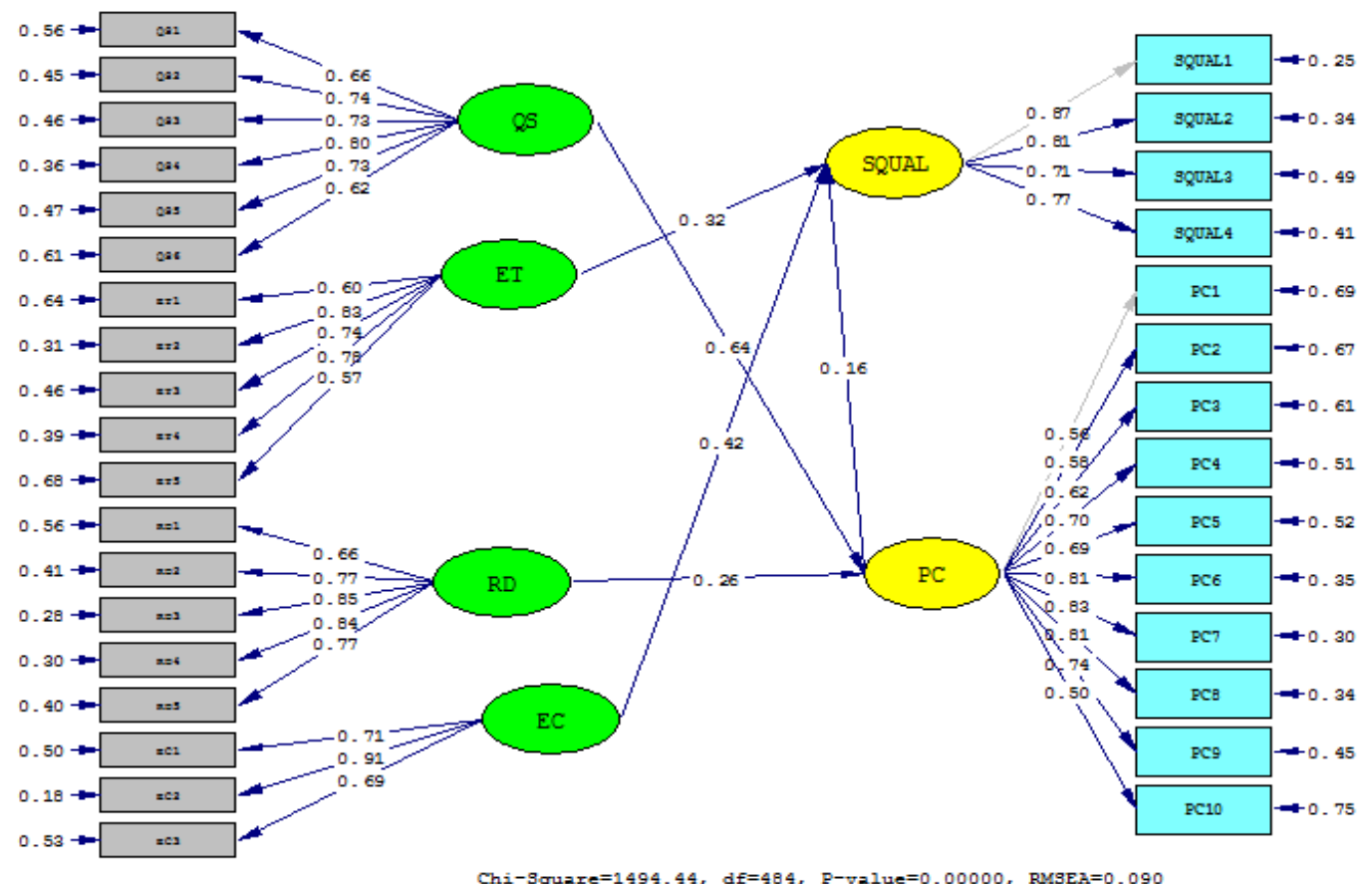

Figure2. Standardized SEM

Table3. Parameter sheet of model estimation

\begin{tabular}{c|c|c|c|c|c|c|c}
\hline Fit index & $\chi^{2} / d f$ & NFI & CFI & IFI & RMSEA & PGFI & PNFI \\
\hline index value & 3.08 & 0.93 & 0.95 & 0.95 & 0.09 & 0.64 & 0.85 \\
\hline $\begin{array}{c}\text { reference } \\
\text { value }\end{array}$ & $<5$ & $>0.9$ & $>0.9$ & $>0.9$ & $<0.1$ & $>0.5$ & $>0.5$ \\
\hline
\end{tabular}

Table4.Validation table of theoretical assumptions

\begin{tabular}{c|lc}
\hline \multicolumn{1}{c}{ theoretical assumptions } & results \\
\hline H1 & quality control standards are positively associated with BPO service quality & support \\
\hline H2 & process control is positively associated with BPO service quality & support \\
\hline H3 & employee-training management is positively associated with BPO service quality & support \\
\hline H4 & treatment of problem correction is positively associated with BPO service quality & support \\
\hline H5 & the platform construction is positively associated with BPO service quality & support \\
\hline H6 & quality control standards are positively associated with process control & nonsupport \\
\hline H7 & employee-training management is positively associated with process control & support \\
\hline H8 & treatment of problem correction is positively associated with process control & nonsupport \\
\hline H9 & the platform construction is positively associated with process control & \\
\hline
\end{tabular}


H5: The platform construction is positively associated with BPO service quality.

H6: Quality control standards are positively associated with process control.

H7 : Employee-training management is positively associated with process control.

H8 : Treatment of problem correction is positively associated with process control.

H9: The platform construction is positively associated with process control.

\section{THE INFLUENTIAL FACTORS OF BPO SERVICE QUALITY SEM}

This paper takes advantage of SEM to analyze the relationship among the influential factors of BPO service quality. In this SEM, the service quality is endogenous latent variable, as well as quality control standards, process control, employee training, treatment of problem correction, platform construction are exogenous latent variables, moreover 33 measurement indexes corresponding to latent variables are observed variables. Measurement model reflects the relationship between the latent variables and the observed variables; structural model reflects the structural relationship among latent variables. This paper makes a path analysis of data obtained from questionnaires by LISREL8.70 and deals with the relationship between variables and factors according to model structure. SEM obtained after several amendments is shown in Figure 2:

\section{MODEL RETESTING}

Some indexes obtained from calculating by LISREL8.70 are shown in Table 3:

As can be seen from the table, value-added fit index $(\mathrm{NFI}=0.93>0.9$, CFI $=0.95>0.9$, IFI $=0.95>0.9) \mathrm{NFI}, \mathrm{IFI}$ and CFI completely measure up to the standards after comparing value-added fitindex with the reference value.

Moreover, the absolute goodness of fit index ( $\chi^{2} / d f=$ $3.08<5$, RMSEA $=0.09<0.1$ ) have reached acceptable standard values after comparing absolute goodness of fit index with the reference value. In addition, PNFI and PGFI $(\mathrm{PNFI}=0.85>0.5, \mathrm{PGFI}=0.64>0.5)$ measure up to the standards after comparing simple fit index with the reference value. Conclusions as a result, good PGFI indicates that the model is relatively simple and further proves that this SEM has a very high fitting precision.

\section{RESEARCH HYPOTHESIS TESTING}

According to the suggestions of the Bollen, we estimate the relationship strength of each causal path by adopting methods to examine the direct impact coefficient among potential variables and the total impact. By computing the correlation coefficient of the path map, the coefficient of direct effects and indirect effects are obtained as follows:

1. There is an indirect correlation between quality control standards and BPO service quality. Path coefficient is equal to 0.80 and value of $\mathrm{P}$ is less than 0.001 . The correlation reaches the level of significance, so the hypothesis $\mathrm{H} 1$ has gained support.

2. There is a direct correlation between process control and BPO service quality. Path coefficient is equal to 0.16 and value of $P$ is less than 0.001 . The correlation reaches the level of significance, so the hypothesis $\mathrm{H} 2$ has gained support.

3 . There is a direct correlation between employeetraining management and BPO service quality. Path coefficient is equal to 0.32 and value of $P$ is less than 0.001 . The correlation reaches the level of significance, so the hypothesis $\mathrm{H} 3$ has gained support.

4. There is an indirect correlation between treatment of problem correction and BPO service quality. Path coefficient is equal to 0.42 and value of $\mathrm{P}$ is less than 0.001 . The correlation reaches the level of significance, so the hypothesis $\mathrm{H} 4$ has gained support.

5. There is a direct correlation between platform construction and BPO service quality. Path coefficient is equal to 0.41 and value of $\mathrm{P}$ is less than 0.001 . The correlation reaches the level of significance, so the hypothesis $\mathrm{H} 5$ has gained support.

6. There is a direct correlation between quality control standards and BPO service quality. Path coefficient is equal to 0.64 and value of $\mathrm{P}$ is less than 0.001 . The correlation reaches the level of significance, so the hypothesis H6 has gained support.

7、 There is no significant path coefficient between employee-training management and process control, so the hypothesis H6 has not gained support.

8. There is a direct correlation between treatment of problem correction and process control. Path coefficient is equal to 0.26 and value of $\mathrm{P}$ is less than 0.001 . The correlation reaches the level of significance, so the hypothesis $\mathrm{H} 8$ has gained support.

9、 There is no significant path coefficient between platform construction and process control, so the hypothesis H9 has not gained support.

Conclusions as a result, testing results of research hypothesis are shown in Table 4.

\section{CONCLUSION}

First, influential factors of BPO service quality are complicated because it is a result of multiple factors driving action. Process control, employee-training management and platform construction directly affects BPO service quality. Quality control standards and treatment of problem correction indirectly affects BPO service quality through their effects on process control.

Secondly, this paper calculates the path coefficients between each factor and BPO service quality as well as the path-correlation coefficient among the factors. As can be seen from the model roadmap of influential factors of BPO service quality, quality control standards play a decisive role for the process control (The path coefficient is equal to 0.64 ). 
Quality control standards make an indirect impact on the BPO service quality (The overall path coefficient reaches 0.80 ). And the overall path coefficient between treatment of problem correction and BPO service quality is equal to 0.42 . In addition, employee-training management, which is directly determined the overall quality of workforce, have a direct impact on BPO services quality (The path coefficient is equal to 0.32). Moreover, platform construction, which can guarantee BPO smooth operation, have a direct impact on BPO services quality (The path coefficient is equal to $0.41)$.

\section{REFERENCE}

[1] King W R, Torkzadeh G. Information Systems Offshoring: Research Status and Issues [J].MIS Quarterly, 2008, 32(2):205-225.

[2] Lee J N. Exploring the Vendor's Process Model in Information Technology Outsourcing $[\mathrm{J}]$. Communications of the Association for Information Systems, 2008, 22(31):569-588.

[3] Miller A. Financial Crisis and IT Outsourcing-What's next? [J].Dialogue Magazine, November 26, 2008:14-15.
[4] Michael Corbett. The Outsourcing Revolution: Why It Makes Sense and How to Do It Right [M]. Dearborn Trade Publishing, A Kaplan Professional Company,2004.

[5] Mahnke,V. The Process of Vertical Disintegration: an Evolutionary Perspective on Outsourcing [J]. Journal of Management and Governance,No.1.:124.

[6] Kalakumari,T.. Business Process Outsourcing in India,in S. Nakkiran and D John Franklin, ed. Business Process Outsourcing: Concept, Current Trends, Management, Future Challenges, Deep \&Deep Publications Ptv. Ltd., New Delhi,2005:69-72.

[7] Laura L. Pfannenstein, Ray J. Tsai. Offshore Outsourcing: Current and Future Effects on American IT Industry [J]. Information System Management, 2004(Fall):72-80.

[8] Andzelika Lonetowicz, Dalia Marin, Alexander Raubold. Is human capital losing from outsourcing? [J]. Evidence for Austria and Poland,2003(10).

[9] Ronald W. Jones. Immigration vs. Outsourcing: Effects on Labor Markets [J]. International Review of Economics and Finance, 2005(14):105-114.

[10] Feeny D,Lacity M, Willcokes L. Taking the Measure of Outsourcing Providers. Sloan Management Review,2005,46 (3):41-48. 